OPTIMUM. ECONOMIC STUDIES NR 2 (92) 2018

\author{
Michał WOJCIUK, MA \\ Faculty of Economics and Management, University of Bialystok \\ e-mail: m.wojciuk@uwb.edu.pl
}

DOI: 10.15290/oes.2018.02.92.11

\title{
LABOR TAXATION VERSUS EMPLOYMENT MODELS IN POLAND
}

\begin{abstract}
Summary
The purpose of the paper is to present the tax wedge observed in Poland and its structure for various models of employment, as well as to find out which of these models is burdened with the highest non-wage expenses. The study uses the descriptive method, statistical data analysis, and the author's own calculations. OECD statistical data and legal regulations concerning labor taxation in Poland are used as source material. The research made it possible to draw the conclusion that an employment contract is the least beneficial form of employment in terms of the non-wage expenses that the tax wedge in Poland comprises. The diversity of labor taxation depending on the form of employment may have a negative effect on the labor market. It prompts many people to choose self-employment or work on the basis of civil-law contracts. The research conducted for the needs of this paper contributes to the body of knowledge on tax and para-tax burdens on labor in Poland, and the conclusions can provide a basis for a debate on necessary changes in Polish legislation regarding taxation of labor so that it becomes more conducive to jobs creation and legal employment
\end{abstract}

Key words: labor taxation, tax wedge, labor costs

JEL: J32, H24, H20

\section{Introduction}

In Poland, an employment contract is the most common type of agreement between employers and employees. However, in the past few years, the former have more and more frequently been resorting to other employment forms. With the dynamically changing and increasingly complex labor market, as well as the growing popularity of non-standard employment practices ${ }^{1}$, employers have been choosing other solutions: civil-law contracts or so-called self-employment [GUS, 2016, p. 1]. The application of non-standard employment models can have either a positive or negative dimension. It is positive when both sides, i.e. employer and employee, agree upon the conditions

\footnotetext{
1 Non-standard employment forms mean employment on the basis of contracts other than an employment contract and not regulated by the Labor Code; they include: civil contract, specific task contract, and self-employment [Bąk, 2009, p. 11].
} 
specified in the contract and accept them. The negative dimension of nonstandard employment is associated above all with excessive non-wage labor costs because of which employees are often forced to conclude a contract other than an employment contract or to register their own companies in order to make it possible for the employer to reduce personnel employment costs. Therefore, the following questions arise: What is the impact of labor taxation on selection of an employment model? What are the non-wage labor costs in Poland in the case of various employment models? Which form of employment is the least beneficial as regards non-wage costs?

The aim of the paper is to present the tax wedge observed in Poland and its structure for particular employment models, as well as to analyze which of these models is burdened with the highest non-wage labor expenses. The author proposes the thesis that the least beneficial model in terms of the sum of nonwage costs creating the tax wedge in Poland, both for the employee and for the employer, is employment based on an employment contract. The diversification of labor taxation according to employment model may contribute to the selection of self-employment or so-called junk contracts.

The study uses the descriptive method, statistical data analysis, and author's own calculations. OECD statistical data and legal regulations regarding labor taxation in Poland are used as source material.

\section{Tax wedge versus labor market: the theoretical aspect}

The total expenditures incurred by an employer and connected with the employment of a worker are referred to as labor costs. They are divided into wage costs: the net remuneration for an employee, and non-wage costs, which include, among other things the cost of social and health insurance contributions and the income tax [Polarczyk, 2007, p. 1]. In the subject literature, the non-wage costs of employing a worker are referred to as the tax wedge or labor taxation ${ }^{2}$ [Sawulski, 2016, p. 1]. K. Polarczyk defines the tax wedge as the difference between the labor costs incurred by an employer owing to the employment of a worker and the net remuneration received by the worker [Polarczyk, 2008, p. 9]. According to P. Arak, the tax wedge is the sum of tributes demanded by the state in connection with the contract signed by the employer and employee [Arak, 2016, p. 9].

Labor taxation has an impact on the behavior of labor market participants. Discouraged by the high non-wage costs of employing staff, employers frequently resign from creating new jobs or shift employment into the grey zone [Nadolny, 2009, p. 11]. Potential employees, on the other hand, abandon their

2 Labor taxation denotes the entirety of tax and para-tax burdens imposed on labor, which include, among other things, the costs of PIT taxation, social insurance contributions, or health insurance contributions, financed both by employee and employer. 
search for work when non-wage costs considerably reduce the net value of their remuneration [Nadolny, 2009, p. 11]. As a result, both labor demand and supply diminish, which may consequently lead to increased unemployment and/or expansion of the grey market.

High non-wage costs of employment are a reason for a number of negative phenomena in the labor market. In order to reduce the costs related to employing staff, employers select employment models that are considerably less burdened with non-wage costs than employment contracts, and frequently compel their employees to accept them. This can be confirmed by the results of an analysis which found that as many as $82 \%$ of the persons working on civil-law contracts in 2014 for whom it was the primary source of income had not chosen this form of employment voluntarily [GUS, 2016, p. 4]. Civil-law contracts are, moreover, beneficial to employers because they do not guarantee the workers such rights as holiday pay, notice period, or severance pay. Additionally, it should be remembered that the reduction of workers' rights provided by the Labor Code may adversely affect the attitudes of employees.

In 2012, excessively high taxes were the main barrier to economic activity in Poland (56.08\% of the survey opinions), whereas the second most significant restriction was related to high non-wage costs related to employment $(47.23 \%$ of the survey opinions), which ensues from a survey administered in that year among micro-entrepreneurs asked to assess the conditions for running a business in Poland [Idea Bank, 2012, p. 5] ${ }^{3}$. In 2016, the most important barrier to business activity in Poland were the costs of labor - according to $69 \%$ of the interviewed persons. High taxes as a hindrance to business activity ranked 6th, indicated by $45 \%$ of the surveyed entrepreneurs from the sector of small and medium enterprises [ZPP, 2016, p. 2] $]^{4}$. In the same survey, $72 \%$ of the respondents regarded too high costs of employing an employee as one of the major reasons for not employing additional staff in small and medium-sized enterprises [ZPP, 2016, p. 5].

\section{Taxation of labor in Poland in comparison with OECD countries}

Poland is not the only country struggling with high non-wage costs of employment. In many member countries of the Organisation for Economic Cooperation and Development (OECD) ${ }^{5}$ there also exists the problem of high labor costs caused by excessive taxation of labor. Comparisons of the levels and

3 Respondents were asked to select a maximum of five barriers, which is why the presented results could not add up to $100 \%$ [Idea Bank, 2012, p. 4].

4 Respondents were asked to indicate more than one answer, which is why the sum of the presented results exceeds $100 \%$ [ZPP, 2016].

5 International Economic Organisation comprising 34 highly developed countries from all over the world which accept the principles of democracy and market economy [MSZ]. 
structures of non-wage costs that constitute the tax wedge between countries is possible when its value is expressed in a percentage form [Rosiński, 2013, p. 362]. The tax wedge is the ratio of the sum of taxes imposed on labor to total labor costs, as presented in a simplified form in the following formula [Krajewska, 2016, p. 670]:

$$
\text { Tax wedge }=\frac{\text { Taxation of labor }}{\text { Labor costs }} \cdot 100 \%
$$

The formula which the OECD methodology employs to calculate the tax wedge is more complex and specifies in detail what components are included in it. The numerator in the formula used by the OECD is the sum of tax burdens from income tax and non-tax burdens, which include social and health insurance contributions paid by an employee, reduced by the value of family benefits. The denominator comprises total labor costs, i.e. the sum of gross value of wages and social insurance contributions paid by an employer [OECD, 2016, p. 1].

The value of the tax wedge largely depends on the amount of non-wage burdens imposed on labor and on their value, which has an influence on the structure of the wedge. Data regarding the value of the tax wedge and its structure in 2015 in OECD member countries is shown in table 1. The countries are listed in decreasing order - from the country with the highest tax wedge to that with the lowest ${ }^{6}$.

TABLE 1

\section{Value and structure of tax wedge for single childless person receiving average wage in 2015 in OECD countries}

\begin{tabular}{|l|c|c|c|c|c|c|c|}
\hline \multirow{2}{*}{ Country } & \multirow{2}{*}{$\begin{array}{c}\text { Tax } \\
\text { wedge }\end{array}$} & $\begin{array}{c}\text { Income } \\
\text { tax }\end{array}$ & $\begin{array}{c}\text { Employee } \\
\text { contribu- } \\
\text { tions }\end{array}$ & $\begin{array}{c}\text { Tanployer } \\
\text { contribu- } \\
\text { tions }\end{array}$ & $\begin{array}{c}\text { Income } \\
\text { tax }\end{array}$ & $\begin{array}{c}\text { Employee } \\
\text { contribu- } \\
\text { tions }\end{array}$ & $\begin{array}{c}\text { Employer } \\
\text { contribu- } \\
\text { tions }\end{array}$ \\
\hline Belgium & 55.3 & 21.6 & 10.8 & 22.9 & 39.11 & 19.51 & 41.39 \\
\hline Austria & 49.5 & 13.1 & 14.0 & 22.4 & 26.39 & 28.29 & 45.32 \\
\hline Germany & 49.4 & 16.1 & 17.2 & 16.2 & 32.53 & 34.71 & 32.76 \\
\hline Hungary & 49.0 & 12.5 & 14.4 & 22.2 & 25.40 & 29.37 & 45.24 \\
\hline France & 48.5 & 10.7 & 10.3 & 27.5 & 22.06 & 21.26 & 56.69 \\
\hline Italy & 47.9 & 16.4 & 7.2 & 24.3 & 34.24 & 15.01 & 50.74 \\
\hline Finland & 43.9 & 18.4 & 6.7 & 18.7 & 41.99 & 15.31 & 42.70 \\
\hline Czech Republic & 42.8 & 9.2 & 8.2 & 25.4 & 21.45 & 19.20 & 59.35 \\
\hline Sweden & 42.7 & 13.5 & 5.3 & 23.9 & 31.54 & 12.47 & 55.98 \\
\hline
\end{tabular}

6 The presented data regard only an employee working on an employment contract. 
Michał Wojciuk

\begin{tabular}{|c|c|c|c|c|c|c|c|}
\hline \multirow[b]{2}{*}{ Country } & \multirow[b]{2}{*}{$\begin{array}{c}\text { Tax } \\
\text { wedge }\end{array}$} & \multicolumn{3}{|c|}{ Tax wedge components } & \multicolumn{3}{|c|}{ Structure in \% } \\
\hline & & $\begin{array}{l}\text { Income } \\
\text { tax }\end{array}$ & $\begin{array}{c}\text { Employee } \\
\text { contribu- } \\
\text { tions }\end{array}$ & $\begin{array}{c}\text { Employer } \\
\text { contribu- } \\
\text { tions }\end{array}$ & $\begin{array}{c}\text { Income } \\
\text { tax }\end{array}$ & $\begin{array}{c}\text { Employee } \\
\text { contribu- } \\
\text { tions }\end{array}$ & $\begin{array}{c}\text { Employer } \\
\text { contribu- } \\
\text { tions }\end{array}$ \\
\hline Slovenia & 42.6 & 9.7 & 19.0 & 13.9 & 22.73 & 44.70 & 32.57 \\
\hline Portugal & 42.1 & 14.0 & 8.9 & 19.2 & 33.23 & 21.14 & 45.63 \\
\hline Slovakia & 41.3 & 7.4 & 10.2 & 23.8 & 17.78 & 24.70 & 57.51 \\
\hline Spain & 39.6 & 11.7 & 4.9 & 23.0 & 29.45 & 12.36 & 58.19 \\
\hline Greece & 39.3 & 7.1 & 12.4 & 19.7 & 18.07 & 31.70 & 50.23 \\
\hline Estonia & 39.0 & 12.6 & 1.2 & 25.3 & 32.21 & 3.06 & 64.73 \\
\hline Luxemburg & 38.3 & 16.0 & 11.4 & 10.9 & 41.68 & 29.80 & 28.53 \\
\hline Turkey & 38.3 & 10.6 & 12.8 & 14.9 & 27.80 & 33.32 & 38.88 \\
\hline Norway & 36.6 & 17.9 & 7.3 & 11.5 & 48.80 & 19.81 & 31.40 \\
\hline Denmark $^{7}$ & 36.4 & 35.8 & 0.0 & 0.8 & 98.32 & 0.00 & 2.32 \\
\hline Netherlands & 36.2 & 15.2 & 12.1 & 8.9 & 41.96 & 33.35 & 24.69 \\
\hline Poland & 34.7 & 5.0 & 15.3 & 14.4 & 14.51 & 44.04 & 41.45 \\
\hline Iceland & 34.0 & 26.7 & 0.3 & 7.0 & 78.53 & 0.99 & 20.48 \\
\hline Japan & 32.2 & 6.7 & 12.4 & 13.1 & 20.84 & 38.57 & 40.59 \\
\hline USA & 31.7 & 16.5 & 7.0 & 8.1 & 52.20 & 22.20 & 25.59 \\
\hline Canada & 31.6 & 14.1 & 6.8 & 10.8 & 44.44 & 21.49 & 34.07 \\
\hline Great Britain & 30.8 & 12.8 & 8.4 & 9.7 & 41.37 & 27.30 & 31.33 \\
\hline Australia & 28.4 & 22.7 & 0.0 & 5.6 & 80.14 & 0.00 & 19.86 \\
\hline Ireland & 27.5 & 14.2 & 3.6 & 9.7 & 51.52 & 13.15 & 35.33 \\
\hline Switzerland & 22.2 & 10.5 & 5.9 & 5.9 & 47.05 & 26.47 & 26.47 \\
\hline South Korea & 21.9 & 4.9 & 7.6 & 9.4 & 22.53 & 34.70 & 42.77 \\
\hline Israel & 21.6 & 8.9 & 7.5 & 5.1 & 41.45 & 34.73 & 23.82 \\
\hline Mexico & 19.7 & 8.0 & 1.2 & 10.5 & 40.60 & 6.17 & 53.23 \\
\hline New Zealand & 17.6 & 17.6 & 0.0 & 0.0 & 100.00 & 0.00 & 0.00 \\
\hline Chile & 7.0 & 0.0 & 7.0 & 0.0 & 0.00 & 100.00 & 0.00 \\
\hline OECD & 35.9 & 13.5 & 8.2 & 14.3 & 37.54 & 22.74 & 39.74 \\
\hline
\end{tabular}

Source: own elaboration based on: OECD database, access mode: [http://stats.oecd.org, date of entry: 04.04.2017].

7 In Denmark, there is one additional element of the tax wedge, under OECD methodology classified as family benefit, which reduces the wedge by $0.2 \%$. It is not included in the table, as a result of which there is no balance between the level of the tax wedge and the sum of its particular elements. Additionally, the sum of the shares of particular elements in the structure exceeds $100 \%$. Moreover, it has an impact on the sums in the last column showing the average value in OECD countries [OECD, 2017]. 
As can be seen, there are considerable differences between the tax wedges in the analyzed countries in 2015. The divergence in the scale of labor taxation was substantial and amounted to $48.3 \%$. The value of the tax wedge ranged from $7.0 \%$ to $55.3 \%$. In 2015, employers in Belgium were burdened with the highest non-wage employment costs, amounting to $55.3 \%$ of the total labor costs. The remaining countries where the levels of labor taxation were considerably higher than the average level for the 34 OECD member countries (35.9\%) included Austria, Germany, Hungary, France, and Italy, where the value of the tax wedge ranged from $47.9 \%$ in Italy to $49.5 \%$ in Austria. The countries with average levels of non-wage burdens, the closest to the OECD average, included Norway, Denmark, the Netherlands, Iceland, and Poland (which ranked 14th among the analyzed countries in terms of the value of the tax wedge). In this group, the level of the tax wedge ranged from $34.0 \%$ to $36.6 \%$. This means that according to the above data Poland is a country with an average level of labor taxation in comparison with the analyzed OECD countries. However, it should be noted that the actual level of the tax wedge in Poland in the case of employment contracts is much higher than that calculated using the methodology used by the $\mathrm{OECD}^{8}$. The size of the tax wedge in Poland in 2015, calculated accounting for all the non-wage burdens not comprised in the OECD methodology, amounted to $40.85 \%$, which indicates that the actual level of labor taxation in Poland is higher than the average level in OECD countries ${ }^{9}$. In 2015, the country with the most convenient conditions for employment (as regards the level of non-wage burdens imposed on labor) was Chile, where the tax wedge was lower than the OECD average by $28.9 \%$ and amounted to $7.0 \%$.

In 2015, also the structures of the tax wedges differed considerably from one country to another. In 28 of the analyzed countries, the insurance premiums paid by the employee and employer made up the largest share in the tax wedge, whereas in the remaining six countries (Ireland, USA, Iceland, Australia, Denmark, and New Zealand), it was the income tax paid by an employee that constituted the higher share. In 2015, Poland was the country with the largest share of insurance premiums paid in total by the employee and employer - they constituted $85.49 \%$ of the tax wedge, while the average OECD value amounted to $62.48 \%{ }^{10}$. This means that in Poland, it was the quasi-fiscal

8 Differences in the levels of the tax wedge result from the fact that in the methodology used by the OECD part of the pension contribution paid to OFE and a sub-account in ZUS (which amounts overall to $7.3 \%$ ) is not classified as a non-wage cost [OECD, 2010, p. 47]. Another difference is the incorrectly calculated income tax with the use of the tax scale, where it is twice reduced by the sum decreasing the tax.

9 Author's own calculation.

10 Chile was an extreme case of a country where $100 \%$ of the tax wedge was made up by insurance contributions paid by the employee; in Chile, it was not necessary to pay the income tax in the case of employees earning $100 \%$ of the average remuneration. This was because of the construction of the tax scale, in which the first tax threshold was higher than the average remuneration in 2015 [KPMG]. 
burdens imposed on labor in the form of insurance contributions that were mainly to blame for the increased costs of labor. The social insurance contributions paid by a Polish employee in 2015 constituted $44.04 \%$ of the tax wedge and were $2.59 \%$ higher than the premiums paid by the employer, which is nonstandard, taking into consideration the fact that such a situation occurred only in Chile and Slovenia.

\section{Diversification of tax wedges for various employment models}

In Poland, in the case of various employment forms the tax wedge is diversified not only in terms of value, but also in terms of structure. This results chiefly from the varying obligations (depending on the form of employment) regarding the payment of contributions for social and health insurance as well as premiums financed by the employer. Data on the obligatory contributions and their percentage value for various employment forms in 2017 are presented in table $2^{11}$.

The percentage values of the contributions paid by the employee and employer are identical, irrespective of employment form. The value of the pension contribution amounts to $19.52 \%$ and is financed by the employee and employer in equal amounts, i.e. both sides of the contract pay a contribution of $9.76 \%$ of the employee's gross remuneration. The value of the disability contribution partly financed by the employee amounts to $1.5 \%$, whereas its part financed by the employer $-6.5 \%$. A self-employed person pays all the contributions by himself, so the rates of retirement and disability contributions amount to $19.52 \%$ and $8 \%$, respectively, and correspond with the sum of the contributions paid by an employee and employer in the case of an employment contract or civillaw contract. The sickness and health contributions are entirely financed by the employee and amount to $2.45 \%$ and $9 \%$, respectively. The accident contribution as well as the contribution for Labour Fund and Guaranteed Employee Benefit Fund are financed solely by the employer and amount to $1.8 \%, 2.45 \%$, and $0.1 \%$, respectively ${ }^{12}$. A significant difference between the particular employment forms is that the obligation to pay certain contributions depends on the type of contract signed by the employer and employee, which considerably affects the size of the tax wedge.

Working on an employment contract is associated with the necessity to pay all the contributions included in obligatory social and health insurance, as well

11 The author assumes that the employee receives remuneration from only one employer and earns at least the minimum gross wage of 2,000 PLN.

12 The author of the analysis does not include the contributions for Temporary Retirement Fund (Fundusz Emerytur Pomostowych) owing to the fact that they do not concern all the employees, but only some employees who meet the requirements specified in the Act [Ustawa..., 2008, art. 35]. 
TABLE 2

\section{Obligatory contributions paid by employee and employer making up tax wedge in 2017 for various employment forms}

\begin{tabular}{|l|c|c|c|c|c|c|c|}
\hline \multirow{2}{*}{ Type of contribution } & \multicolumn{6}{|c|}{$\begin{array}{c}\text { Percentage of contribution partly financed by employee (Z) } \\
\text { and employer (P) when employed on the basis of: }\end{array}$} \\
\cline { 2 - 9 } & $\begin{array}{c}\text { Employment } \\
\text { contract }\end{array}$ & \multicolumn{2}{|c|}{$\begin{array}{c}\text { Civil } \\
\text { contract }\end{array}$} & $\begin{array}{c}\text { Specific-task } \\
\text { contract }\end{array}$ & $\begin{array}{c}\text { Self-employment } \\
\text { (business activity) }\end{array}$ \\
\cline { 2 - 9 } & $\mathrm{Z}$ & $\mathrm{P}$ & $\mathrm{Z}$ & $\mathrm{P}$ & $\mathrm{Z}$ & $\mathrm{P}$ & $\mathrm{Z}$ \\
\hline $\begin{array}{l}\text { 1. Social insurance } \\
\text { contributions }\end{array}$ & 13.71 & 18.06 & 11.26 & 18.06 & - & - & 31.77 \\
a) retirement & 9.76 & 9.76 & 9.76 & 9.76 & - & - & 19.52 \\
b) disability & 1.5 & 6.5 & 1.5 & 6.5 & - & - & 8 \\
c) sickness & 2.45 & - & - & - & - & - & $2.45^{13}$ \\
d) accident & - & 1.8 & - & 1.8 & - & - & 1.8 \\
\hline 2. Health insurance & 9 & - & 9 & - & - & - & 9 \\
contribution & & & & & & - & 2.45 \\
\hline 3. Other contributions & - & 2.55 & - & 2.55 & - & - & 2.45 \\
a) FP (Labour Fund) & - & 2.45 & - & 2.45 & - & - & - \\
b) FGŚP (Guaranteed & - & 0.1 & - & 0.1 & - & - & \\
$\begin{array}{l}\text { Employee Benefit } \\
\text { Fund) }\end{array}$ & & & & & & & \\
\hline
\end{tabular}

Source: own elaboration based on: [Ustawa..., 1998; Ustawa..., 2004; Ustawa..., 2004; Ustawa..., 2006; Ustawa budżetowa...; ZUS, 2017].

as the remaining contributions financed solely by the employer. Polish regulations specify the revenue threshold (thirty times the value of anticipated average remuneration) for which pension and disability contributions are no longer calculated [Ustawa..., 1998, art. 19 act 1]. In 2017, the threshold per year was 127,890 PLN for anticipated average remuneration amounting to 4,263 PLN per month [Ustawa..., 2017].

Signing a civil contract entails the necessity to pay all the contributions, excluding the contribution for medical (sickness) insurance, which can be paid on a voluntary basis by the employee. The situation is different when more than one civil-law contract is signed by the employer and employee ${ }^{15}$. In this case, if one contract is concluded for remuneration whose value is not lower

13 The sickness insurance contribution in the case of business activity is voluntary; however, for the needs of the research the author assumes that a self-employed person who conducts business activity pays the sickness insurance contribution.

14 The author assumes that the accident insurance contribution amounts to $1.80 \%$ and is obligatory for taxpayers who register less than 9 persons for accident insurance.

15 Assuming that the scope of duties for each contract differs. 
than the minimum wage and all the necessary contributions are paid, in the case of another contract only the health insurance contribution must be paid [Ustawa..., 1998, art. 9 part 2c, art. 12 part 1; Ustawa..., 2004, art. 104; Ustawa..., 2004, art. 82; Ustawa..., 2006, art. 9, art. 10]. This makes it possible to considerably reduce the non-wage costs of employment, thus reducing the level of the tax wedge ${ }^{16}$.

Specific-task contracts do not entail the necessity to pay any contributions. The lack of an obligation to pay the contributions related to a contract of this type greatly decreases the size of the tax wedge in comparison to an employment contract or a civil contract. It also affects the structure of the wedge since it comprises solely the income tax paid by the employee.

The last analyzed employment form is so-called self-employment, i.e. the situation when an employee conducts his/her own business activity and within its framework performs assignments for the employer. As regards this employment form, the employee makes all the contributions on his/her own. The percentage rates of particular contributions are the same as in the other employment forms, but in this case, the legislator imposes minimum assessment bases for the contributions [ZUS, 2017]. As a result, entrepreneurs (regardless of their income) have the obligation to pay contributions at least as high as those specified by the legislator. In 2017, the sum of the minimum contributions paid by self-employed persons amounted to 1,172.56 PLN monthly [ZUS, 2017]. If an employee decided to pay obligatory minimum contributions irrespective of obtained income, the costs related to the contributions would not increase together with rising remuneration, which would enable a considerable reduction in non-wage costs of employment.

Labor taxation in Poland includes not only social and health insurance contributions paid by employees and employers, but also an income tax, entirely financed by the employee. The incomes achieved by employees from their work based on an employment contract or a civil contract are subject to taxation under general rules in accordance with the progressive tax scale with two income thresholds and two tax rates. For the tax base that is either lower than or equal to the sum of 85,528 PLN, the tax rate amounts to $18 \%$, whereas for sums higher than this value the rate of taxation is $32 \%$. The construction of the tax scale takes into consideration a tax allowance in the form of a sum that reduces the tax base and contributes to reducing the value of the income tax paid. Until the end of 2016, the tax allowance amounted to 3,091 PLN, irrespective of the level of income. New regulations regarding tax-free allowance that make the value of the allowance dependent on the level of the tax base have been in force since 1 January 2017. The increased tax-free allowance is applicable for

16 The author assumes for the needs of the analysis that signing a civil-law contract, i.e. a commission contract or a specific task contract between an employee and an employer does not have the attributes of an employment contract and is compliant with the labor law regulations. 
the tax base lower than 11,000 PLN. The tax-free allowance for incomes from 11,000 PLN to 85,528 PLN did not change and still equals 3,091 PLN, whereas above the threshold level of the tax scale (to 127,000 PLN), it is systematically reduced to 0 PLN. The tax allowance sum does not apply for tax basis exceeding 127,000 PLN [Ustawa..., 1991, art. 27]. This means that modifications in the tax-free allowance contribute to reducing the tax wedge in the case of persons on incomes lower than 11,000 PLN. On the other hand, the increase in the tax wedge resulting from these modifications will take place in the case of persons having incomes higher than 85,528 PLN. In the case of other persons with incomes ranging from 11,000 PLN to 85,28 PLN, the modifications in the tax allowance will not cause changes in the level of the tax wedge because the tax allowance did not change ${ }^{17}$.

Self-employed persons who conduct business activity in Poland, as a rule, have the obligation to pay taxes under general principles, in accordance with the tax scale, similarly to persons on employment contracts or civil contracts. However, they can select another form of taxation, i.e. a flat rate general tax ${ }^{18}$. In this case, irrespective of the value of obtained income, the tax rate amounts to $19 \%$. The tax-free allowance is not applicable for this taxation form.

Considerable diversity can be observed as regards the level of the tax wedge among the analyzed forms of employment. The highest taxation of labor applies in the case of the employment contract, where the tax wedge for a person receiving average anticipated remuneration amounts to $40.94 \%$. The tax wedge in the case of self-employment is $6.22 \%$ lower and amounts to $34.72 \%$, assuming that the employee calculates income tax using the tax scale. If the $19 \%$ flat rate is used, the tax wedge is slightly higher: $(36.60 \%)$. As far as commission contracts are concerned, the tax wedge stands at $26.16 \%$, whereas as regards specifictask contracts, for which $20 \%$ of tax deductible expenses (TDE) is applicable, it amounts to $13.31 \%$. The lowest non-wage costs occur in a specific task contract, for which $50 \%$ of TDE is applied. The level of the tax wedge for this type of contract is $33.03 \%$ lower than the highest wedge level occurring in employment contract and amounts to $7.91 \%$. This means that labor taxation in the case of an employment contract is more than 5 times as high as it is in the case of a specific-task contract, for which $50 \%$ of TDE can be applied. However, one needs to remember that despite the high tax wedge, working on an employment contract is quite beneficial to employees since they are legally entitled to such privileges as vacation benefits, severance payments, or periods of notice.

17 Polish laws regarding income tax for physical persons provide various forms of tax reliefs and exemptions for taxpayers who meet certain conditions, but as they fall beyond the scope of this paper, the author does not describe them.

18 Persons who conduct business activity in Poland, provided they meet certain requirements, may select not only the above mentioned forms of taxation but also others, i.e. tax on registered income without deductible costs or fixed amount tax. The author does not describe them in detail because they will not be taken into consideration in this analysis. 
TABLE 3

\section{Structure of tax wedge for single childless person receiving average anticipated remuneration in 2017 in Poland for various employment forms}

\begin{tabular}{|c|c|c|c|c|c|c|c|}
\hline \multirow[b]{2}{*}{$\begin{array}{l}\text { Employment } \\
\text { model }\end{array}$} & \multirow[b]{2}{*}{$\begin{array}{c}\text { Tax } \\
\text { wedge }\end{array}$} & \multicolumn{3}{|c|}{ Tax wedge components } & \multicolumn{3}{|c|}{ Structure in $\%$} \\
\hline & & $\begin{array}{l}\text { Income } \\
\text { tax }\end{array}$ & $\begin{array}{c}\text { Employee } \\
\text { contribu- } \\
\text { tions }\end{array}$ & $\begin{array}{c}\text { Employer } \\
\text { contribu- } \\
\text { tions }\end{array}$ & $\begin{array}{l}\text { Income } \\
\text { tax }\end{array}$ & $\begin{array}{c}\text { Employee } \\
\text { contribu- } \\
\text { tions }\end{array}$ & $\begin{array}{c}\text { Employer } \\
\text { contribu- } \\
\text { tions }\end{array}$ \\
\hline Employment contract & 40.94 & 6.04 & 17.81 & 17.09 & 14.75 & 43.50 & 41.74 \\
\hline Civil contract ${ }^{19}$ & 26.16 & 4.75 & 12.59 & 8.82 & 18.16 & 48.13 & 33.72 \\
\hline $\begin{array}{l}\text { Specific-task contract } \\
\text { (20\% tax deductible } \\
\text { revenue })\end{array}$ & 13.31 & 13.31 & 0.00 & 0.00 & 100.00 & 0.00 & 0.00 \\
\hline $\begin{array}{l}\text { Specific-task contract } \\
(50 \% \text { tax deductible } \\
\text { revenue })^{20}\end{array}$ & 7.91 & 7.91 & 0.00 & 0.00 & 100.00 & 0.00 & 0.00 \\
\hline $\begin{array}{l}\text { Business activity } \\
\text { (tax scale) }\end{array}$ & 34.72 & 7.21 & 27.51 & 0.00 & 20.77 & 79.23 & 0.00 \\
\hline $\begin{array}{l}\text { Business activity } \\
\text { (flat tax) }\end{array}$ & 36.60 & 9.09 & 27.51 & 0.00 & 24.84 & 75.16 & 0.00 \\
\hline
\end{tabular}

Source: own elaboration based on: [Ustawa..., 1991; Ustawa..., 1998; Ustawa..., 2004; Ustawa..., 2004; Ustawa..., 2006; Ustawa budżetowa...; ZUS, 2017].

The structure of the tax wedges for the presented employment forms is also diversified. This is mainly because, depending on the employment form, the obligations related to the individual contributions paid by employees and employers vary. The highest level of contributions paid by an employer in the tax wedge is observed in the employment contract, where the level/participation amounts to $41.74 \%$. For the civil contract, this is $33.72 \%$, whereas in the remaining employment forms, it equals $0 \%$. The highest level of contributions paid by an employee in the tax wedge occurs in self-employment, which results from the fact that a self-employed person running a business activity must pay all the obligatory contributions by himself/herself and pay the income tax. In this employment form, the contributions paid by an employee constitute $79.23 \%$ or $75.16 \%$ of the tax wedge, depending on the selected form of the income tax. For employment contracts and civil contracts, they amount

19 For the needs of the analysis, the author assumes that the retirement, disability, and accident contributions as well as contributions for FP and FGŚP are paid to the level of the minimal wage, which amounts to 2,000 PLN.

20 Specific-task contract with $50 \%$ rate of tax deductible costs on the basis of using copyright laws and similar rights by artists and performers [Ustawa..., 1991, art. 22 act 9 pt 3]. 
to $43.50 \%$ and $48.13 \%$ of the tax wedge, respectively. In the case of specifictask contracts, no contributions are paid, owing to which their participation amounts to $0 \%$. In the case of specific-task contracts, the structure of the tax wedge largely differs from the remaining employment forms because the lack of obligation to pay any contributions results in the facts that the income tax paid by the employee in both cases constitutes $100 \%$ of the tax wedge. The level of the income tax paid by the employee in the wedge structure for the remaining employment forms ranges from $14.75 \%$ for the employment contract to $24.84 \%$ for self-employment.

The majority of the presented employment forms are characterized by a high share of contributions paid by employees and employers in the tax wedge, which largely contributes to increasing labor costs. Such a situation is negatively perceived by entrepreneurs and may lead to forcing employees to accept civillaw contracts (so-called junk contracts) or to attempts at shifting employment into the grey zone in order to reduce non-wage labor costs.

The value of the tax wedge is largely dependent on the level of remuneration received by an employee. This results from the fact that all the non-wage burdens imposed on labor constitute a certain percentage of the tax base, which in most cases is determined by obtained incomes. The level of the tax wedge for various employment forms depending on remuneration received by an employee in 2017 is illustrated in chart 1.

The tax wedge is progressive (i.e. it increases simultaneously with increasing remuneration) for specific-task contracts, regardless of the value of received remuneration, as long as the value of income is higher than $250 \%$ of the average anticipated remuneration. When this level is exceeded, the value of the tax wedge decreases, which results from a revenue limit above which it is not obligatory to pay either pension or disability contributions. Despite the progressive character of the tax wedges for these employment forms, the difference between the value of the tax wedge for a person receiving minimum wage in 2017 , i.e. approx. $47 \%$ of the average anticipated remuneration, and the value of the tax wedge for a person receiving $100 \%$ of the average anticipated remuneration is negligible, and in the case of employment contracts, it amounts to $1.46 \%$, whereas for specific-task contracts to $1.22 \%$ This means that employees receiving minimum remuneration have almost identical non-wage burdens as those who earn twice as much.

The tax wedge has a regressive character (i.e. it decreases simultaneously with increasing wage) for civil contracts and self-employment (tax scale) until the level of income that constitutes the basis of taxation is higher than 85,528 PLN (the threshold of the tax scale). When the threshold is exceeded, the wedge level increases because for incomes higher than this amount, the tax rate of $32 \%$ is applied. Regardless of the level of received income, the regressive character of the tax wedge occurs in the case of self-employed persons who choose to pay income tax using the $19 \%$ flat rate. 
CHART 1

Tax wedge for a single childless person with regard to remuneration level in Poland in 2017 for various employment forms
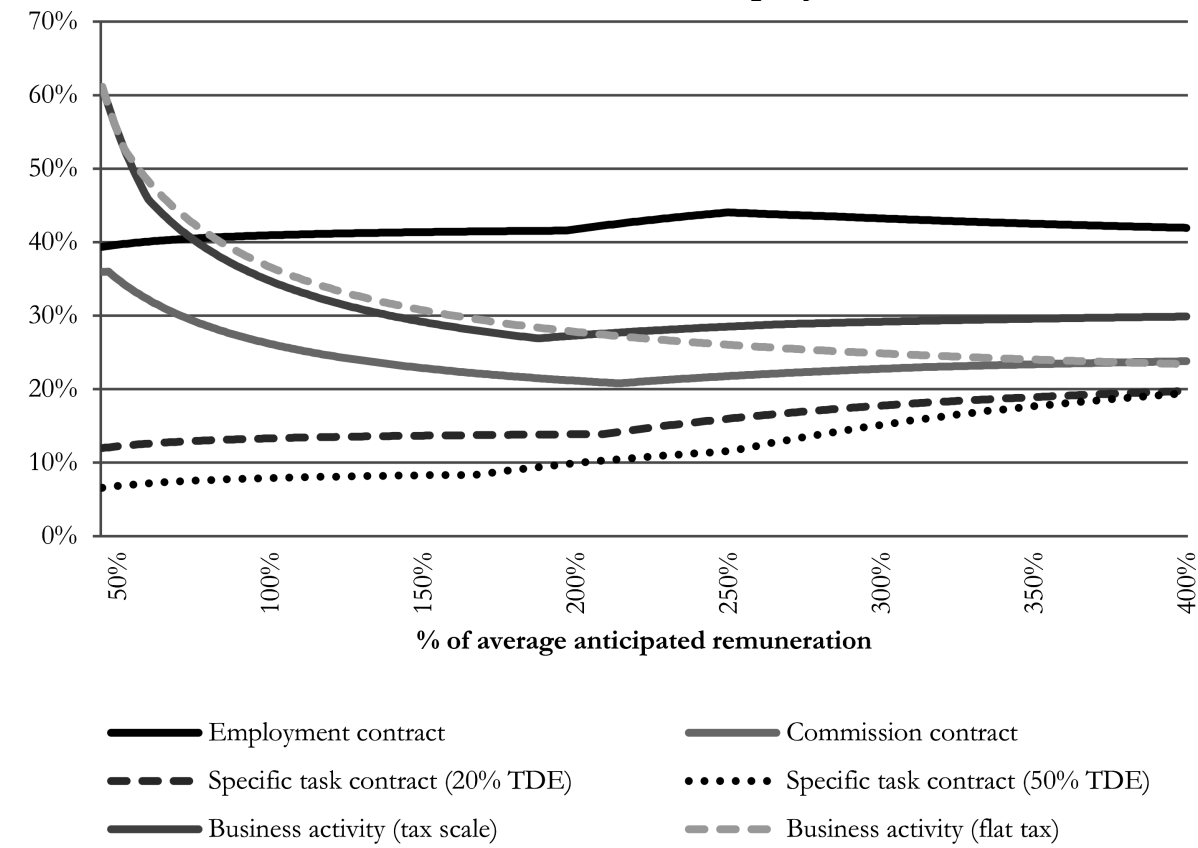

Source: own elaboration based on: [Ustawa..., 1991; Ustawa..., 1998; Ustawa..., 2004; Ustawa..., 2004; Ustawa..., 2006; Ustawa budżetowa...; ZUS, 2017].

\section{Conclusions}

The analysis of the presented statistical data and conducted research make it possible to draw the following conclusions:

1. The level of the tax wedge for employment contracts in Poland, calculated taking into consideration all the non-wage costs not included in the methodology used by the OECD, is higher than the average for 34 OECD countries, in 2015 amounting to $35.9 \%$ of the average remuneration and stands at approx. $40.9 \%$, which justifies the conclusion that the tax wedge in Poland as above average.

2. The level of labor taxation in Poland is dependent on the form of employment and the related obligations connected with paying certain contributions by employees and employers.

3. The high share of social security premiums paid by employees and employers in the structure of the wedge for an employment contract, amounting to $85.24 \%$, contributes to the fact that the level of the tax wedge related to this employment form is the highest among the analyzed forms, in 2017 
amounting to $40.94 \%$, which leads to the conclusion that it is the least beneficial employment form in this regard.

4. Because of the nature of the tax wedges for civil contracts and selfemployment, persons on low wages are the most burdened with non-wage costs.

5. The tax wedge for the presented employment forms is either slightly progressive or not progressive at all, which means that the income situation of the taxpayer is not taken into consideration.

Solutions to the problem regarding high non-wage costs ought to be sought in modifying the laws regarding the obligatory social and health contributions, as well as the contributions paid by entrepreneurs because, in the author's opinion, they constitute the largest burden. The efforts to reduce the tax wedge should mainly focus on the most vulnerable group of employees: those with low qualifications or those who are new to the labor market. Interesting suggestions have been made by K. Polarczyk, who points out that as regards social insurance contributions it would be possible to introduce an amount of remuneration free from the component burdens, excluding the retirement contribution, which is cumulative. As for the income tax, Polarczyk recommends that the flat-rate tax deductible costs and tax allowances are increased [Polarczyk, 2007, p. 3]. E. Kryńska presents three ways to reduce the tax wedge of persons with low qualifications. Firstly, she indicates the possibility of subsidizing their employment from public funds in the form of employee benefits. Secondly, she suggests reducing the burdens related to social insurance contributions (excluding the retirement contribution) and income tax. Thirdly, she proposes that tax reliefs for those who employ workers are introduced [Kryńska, 2014, pp. 5960]. According to A. Krajewska, it is necessary to enhance the progressiveness of the tax wedge, which will contribute to improving the situation of persons with low qualifications, through, e.g. raising the tax allowance, increasing the number of tax thresholds, expanding tax reliefs, or introducing an exemption or relief from paying insurance contributions [Krajewska, 2016, p. 678] The above solutions would not be sufficient to fully remediate the problem, but they might provide an impulse for implementing changes/modifications in the Polish law.

The research conducted in the paper helps broaden the knowledge of the tax and para-tax burdens levied on labor in Poland, whereas the conclusions can become a basis for discussion on the necessity of changes in the legal provisions regulating labor taxation in Poland so that they become more conducive to job creation and legal employment forms.

\section{References}

Arak P., 2016, Jak naprawić klin podatkowy w Polsce, Polityka Insight, electronic document, access mode: [https://www.politykainsight.pl/multimedia/_re source/res/20105881, date of entry: 08.02.2017]. 
Bąk E., 2009, Nietypowe formy zatrudnienia na rynku pracy, C.H. Beck, Warszawa. GUS, 2016, Pracujacy w nietypowych formach zatrudnienia, electronic document, access mode: [http://stat.gov.pl/download/gfx/portalinformacyjny/pl/ defaultaktualnosci/5821/11/1/1/notatka_nietypowe_formy_zatrudnienia_ 2016_01_27.pdf, date of entry: 10.04.2017].

Idea Bank, 2012, Mikroprzedsiębiorcy oceniają warunki do prowadzenia biznesu, electronic document, access mode: [http://img.interia.pl/biznes/nimg/4/f/ RAPORT_SPECJALNY_oceniaja_6280774.pdf, date of entry: 18.04.2017].

KPMG, electronic document, access mode: [https://home.kpmg.com/xx/en/ home/insights/2015/11/chile-income-tax.html, date of entry: 06.04.2017].

Krajewska A., 2016, Opodatkowanie pracy w OECD. Analiza porównawcza i wnioski dla Polski, "Annales Universitatis Mariae Curie-Skłodowska, Sectio H: Oeconomia", Vol. L, 1.

Kryńska E., 2014, Labour Taxation in Poland Compared To The Other OECD Countries, "Comparative Economic Research. Central and Eastern Europe", Vol. 17, No. 3.

MSZ, electronic document, access mode: [http://www.msz.gov.pl/pl/c/MOBIL E/polityka_zagraniczna/organizacje_miedzynarodowe/oecd/, date of entry: 06.04.2017].

Nadolny Ł., 2009, Klin podatkowy w Polsce na tle krajów Unii Europejskiej, "Polityka Społeczna", No. 5-6.

OECD, 2010, Special Feature: Non-tax Compulsory Payments as an Additional Burden on Labour income, Taxing Wages 2008-2009, electronic document, access mode: [http://www.oecd.org/ctp/tax-policy/45120766.pdf, date of entry: 15.08.2017].

OECD, 2016, Taxing Wages - Poland, electronic document, access mode: [https://www.oecd.org/poland/taxing-wages-poland.pdf, date of entry: 08.02.2017].

OECD, 2017, OECD database, electronic document, access mode: [http://stats. oecd.org, date of entry: 18.04.2017].

Polarczyk K., 2007, Klin podatkowy a bezrobocie, Biuro Analiz Sejmowych, Infos, No. 17.

Polarczyk K., 2008, Opodatkowanie wynagrodzeń za prace (składki i PIT) w państwach Unii Europejskiej, Biuro Analiz Sejmowych, Analizy, nr 6.

Rosiński R., 2013, Zmiany ptacowego klina podatkowego w wybranych krajach Unii Europejskiej w obliczu kryzysu finansów publicznych, "Zarządzanie i Finanse", t. $2, \mathrm{nr} 3$.

Sawulski J., 2016, Jak opodatkować pracę? Propozycja reformy klina podatkowego $w$ Polsce, electronic document, access mode: [http://challenger.ue.poznan.pl /wp-content/uploads/2016/07/Opodatkowanie-pracy.pdf, date of entry: 18.04.2017].

Ustawa budżetowa na rok 2017 (Dz.U. z 2017, poz. 108). 
Ustawa z dnia 13 lipca 2006 r. o ochronie roszczeń pracowniczych w razie niewypłacalności pracodawcy (Dz.U. nr 158, poz. 1121 z późn. zm.).

Ustawa z dnia 13 października 1998 r. o systemie ubezpieczeń społecznych (Dz.U. nr 137, poz. 887 z późn. zm.).

Ustawa z dnia 19 grudnia 2008 r. o emeryturach pomostowych (Dz.U. nr 237, poz. $1656 \mathrm{z}$ późn. zm.).

Ustawa z dnia 20 kwietnia 2004 r. o promocji zatrudnienia i instytucjach rynku pracy (Dz.U. nr 99, poz. 1001 z późn. zm.).

Ustawa z dnia 26 lipca 1991 r. o podatku dochodowym od osób fizycznych (Dz.U. nr 80, poz. 350 z późn. zm.).

Ustawa z dnia 27 sierpnia 2004 r. o świadczeniach opieki zdrowotnej finansowanych ze środków publicznych (Dz.U. nr 210, poz. 2135 z późn. zm.).

ZPP, 2016, Bariery prowadzenia dziatalności gospodarczej w Polsce, electronic document, access mode: [http://zpp.net.pl/files/manager/file-dc6a1f060fb0952 d1274772deca94754.pdf, date of entry: 18.04.2017].

ZUS, 2017, electronic document, access mode: [http://www.zus.pl/baza-wiedzy /skladki-wskazniki-odsetki/skladki/wysokosc-skladek-na-ubezpieczeniaspoleczne, date of entry: 04.04.2017]. 